Western North American Naturalist 71(1), (C) 2011, pp. 78-85

\title{
EXERCISE CONDITIONING DECREASES DOWNSTREAM MOVEMENT OF POND-REARED RAZORBACK SUCKERS RELEASED INTO A STREAM ENVIRONMENT
}

\author{
Luke A. Avery ${ }^{1,3}$ David L. Ward ${ }^{1}$, and Jane C. Marks²
}

\begin{abstract}
Despite augmentation stocking efforts, wild populations of razorback suckers (Xyrauchen texanus) continue to decline. Endangered razorback suckers are commonly raised in off-channel ponds until maturity (approximately 300 mm TL) and then stocked into the Colorado River or its tributaries. After fish are stocked, they commonly move large distances downstream. We conducted an experiment to determine if downstream dispersal could be reduced through exercise conditioning. Two groups of razorback suckers, exercised and nonexercised, were released into Fossil Creek, Arizona. Prior to release, a subsample from each treatment group was tested in a laboratory flow chamber. Razorback suckers that had been exercise conditioned were able to maintain a position in the flow chamber 2 times longer and at velocities $25 \mathrm{~cm} \cdot \mathrm{s}^{-1}$ higher than nonexercised fish. Although the intended method of field data collection via passive-integrated-transponder (PIT) antennas and a remote communication station failed because river otters (Lontra canadensis) preyed upon the released razorback suckers, implanted PIT tags were retained in otter scat. Recovered PIT tags enabled distributional analysis, which indicated that exercised razorback suckers did not move as far downstream from the point of release as nonexercised razorbacks. Exercise conditioning may increase overall fitness of pond-reared razorback suckers, and, consequently, increase the effectiveness of augmentation stocking.
\end{abstract}

RESUMEN.-A pesar de los esfuerzos de repoblación, las poblaciones silvestres del matalote jorobado (Xyrauchen texanus) siguen en declive. Los matalotes jorobados, que están en peligro de extinción, se crían en estanques fuera del cauce hasta la etapa adulta $(\sim 300 \mathrm{~mm})$ y después son liberados en el Río Colorado o uno de sus afluentes. Los peces suelen desplazarse largas distancias río abajo después de su introducción al río. Llevamos a cabo un experimento para determinar si la dispersión río abajo se podía reducir mediante el acondicionamiento por ejercicio. Dos grupos de matalotes fueron liberados en Fossil Creek, Arizona, uno que había sido acondicionado y otro que no. Antes de liberarlos, examinamos una submuestra de cada grupo en una cámara de flujo en el laboratorio. Los matalotes que habían sido acondicionados por ejercicio pudieron mantener sus posición en la cámara de flujo dos veces más tiempo y a velocidades de $25 \mathrm{~cm} \cdot \mathrm{s}^{-1}$ más altas que los peces no acondicionados. Aunque falló el método de colecta de datos mediante antenas de sistema PIT (passive integrated transponder) y una estación remota de comunicación, los matalotes liberados fueron depredados por nutrias de río (Lontra canadensis) y las marcas PIT implantadas se quedaron en las heces de las nutrias. La recuperación de estas etiquetas PIT permitió un análisis de distribución que indicó que los matalotes acondicionados no se desplazaron río abajo tan lejos del punto de liberación como los matalotes no acondicionados. El acondicionamiento por ejercicio podría mejorar la condición física de los matalotes jorobados criados en cautiverio y así aumentar la eficacia de la reintroducción.

Native fishes of the American Southwest have been in decline for decades because of habitat loss (Minckley and Deacon 1968, Miller et al. 1989, Poff and Olden 2005) and the incursion of nonnative fish species (Minckley 1990, Rinne 1995, Tyus and Saunders 2000). Endangered razorback suckers (Xyrauchen texanus) are known to spawn in the wild, but little recruitment occurs because of predation by nonnative fish during early life history stages (Marsh and Langhorst 1988, Marsh and Minckley 1990, Tyus and Karp 1990, Rupert et al. 1993,Modde et al. 1996, Marsh et al. 2003). Augmentation stocking of pond-reared fish is currently used to maintain existing populations (Nesler et al. 2003).
Razorback sucker larvae are either collected from the wild and moved to protected ponds until they reach a suitable size for release (Marsh et al. 2005) or obtained from brood stocks maintained at fish hatcheries. Evidence suggests that survival of these stocked fish is directly linked to size at release, with larger fish having higher survival rates (Marsh et. al 2005); however, even at $300 \mathrm{~mm}$ TL they are susceptible to predation, and few stocked fish survive (Marsh and Brooks 1989, Schooley and Marsh 2007).

Razorback suckers are commonly stocked into the Colorado River (Mueller 2003) and its major tributaries (Nesler et al. 2003, Schooley and Marsh 2007). Upon release, pond-reared

\footnotetext{
${ }^{1}$ Arizona Game and Fish Department, Fish Research, 506 N. Grant St., Suite L, Flagstaff, AZ 86004

${ }^{2}$ Northern Arizona University, Biology, Box 5640, Flagstaff, AZ 86011-5640.

32E-mail: laveryagf@qwestoffice.net
} 
razorback suckers tend to move downstream, often great distances from the release site (Mueller et al. 2003). Razorback suckers migrate long distances as part of their natural life history (Tyus and Karp 1990, Modde and Irving 1998, Mueller 2006). However, under current conditions on the Colorado River, the razorback suckers' natural movement is problematic, because the fish frequently end up in man-made reservoirs or sections of the river that have higher densities of nonnative piscivores (i.e., striped bass Morone saxitilis), leading to low survival rates. Because the magnitude of movement is variable (e.g., 1-92.1 km; Ryden 2000), simply stocking farther upstream, targeting a stocking site that has existing razorback sucker habitat and/or relatively low predator densities, and monitoring the survival of the stocked fish are difficult. The reasons for this poststocking movement are unknown but may be related to behavior, stress, or the conditions under which the fish were raised. Fish that have been reared in ponds without flowing water may not be physiologically able to handle the combination of flowing water and high densities of nonnative predators (Mueller et al. 2003).

Exercise conditioning has been shown to have positive effects on hatchery-reared salmonids and centrarchids, including increased food consumption and growth (Leon 1986, Jobling et al. 1993), increased swimming stamina and critical swimming speed (Leon 1986, Young and Cech 1994a), increased fat and muscle content (Young and Cech 1994a, 1994b), increased hemoglobin, and decreased stress recovery time as measured by cortisol levels in the blood (Farlinger and Beamish 1978, Young and Cech 1993, Young and Cech 1994a). Exercise-conditioning studies conducted on native fishes of the Southwest have been less extensive and less in-depth, but have shown increases in swimming performance for flannelmouth sucker (Catostomus latipinnis), bonytail chub (Gila elegans), spikedace (Meda fulgida), and razorback sucker (Ward et al. 2002, Ward and Hilwig 2004, Mueller et al. 2007). While a study by Mueller et al. (2007) did not show a huge increase in the swimming performance of razorback suckers, it did show lower predation by an ictalurid catfish on exercise-conditioned fish than on nonexercised fish in laboratory trials. A field study conducted by Mueller et al. (2003) with a small sample size showed that exercised razorback suckers moved a shorter distance downstream than nonexercised razorback suckers. Though fish were not tested extensively in the field, lab studies have shown that exercise conditioning can improve physiological condition and swimming capabilities of fish. Exercise conditioning may lead to increased survival in the field (Ward and Hilwig 2004). Furthermore, it may make possible the stocking of fish into targeted sites with greater confidence that the fish will remain within or near those sites. This would improve the effectiveness of poststocking survival assessment.

We conducted an experiment to determine if exercise conditioning could decrease downstream movement of pond-reared razorback suckers released into a stream environment. Two groups of PIT-tagged razorback suckers, exercised and nonexercised, were released into Fossil Creek, Arizona. Fossil Creek was selected as the release site for the experimental razorback suckers because it lacked nonnative species above a concrete barrier that prevents upstream movement of fishes (Fig. 1) and because it is a tributary to the Verde River. Razorback suckers were historically reported in high numbers in the Verde River, and the Verde River has physical characteristics that could allow spawning. While razorback suckers were not reported in Fossil Creek prior to any intentional introductions, managers are interested in introducing razorback suckers into Fossil Creek to give them an opportunity to grow to a larger size before entering the Verde River, which currently contains large numbers of nonnative fishes. Any displacement of razorback suckers below the concrete fish barrier before they have time to grow to a less predator-susceptible size will likely result in high mortality because of predation by nonnative predators. We intended to collect data using 2 remote-detection antennas and a communication station attached to the concrete barrier. The data collection component of the remote communication station ultimately failed. However, predation by river otters (Lontra canadensis) enabled collection of some data on poststocking fish movement.

\section{Study SITE}

Fossil Creek is a first-order stream in central Arizona with a base flow of $1218 \mathrm{~L} \cdot \mathrm{s}^{-1}$ produced almost entirely by a series of springs. The water from the springs is a constant $21^{\circ} \mathrm{C}$ with seasonal variation in temperature increasing downstream. Lows are approximately $16{ }^{\circ} \mathrm{C}$ in the winter, and highs are approximately $24^{\circ} \mathrm{C}$ in the summer. Short-duration high-flow events 


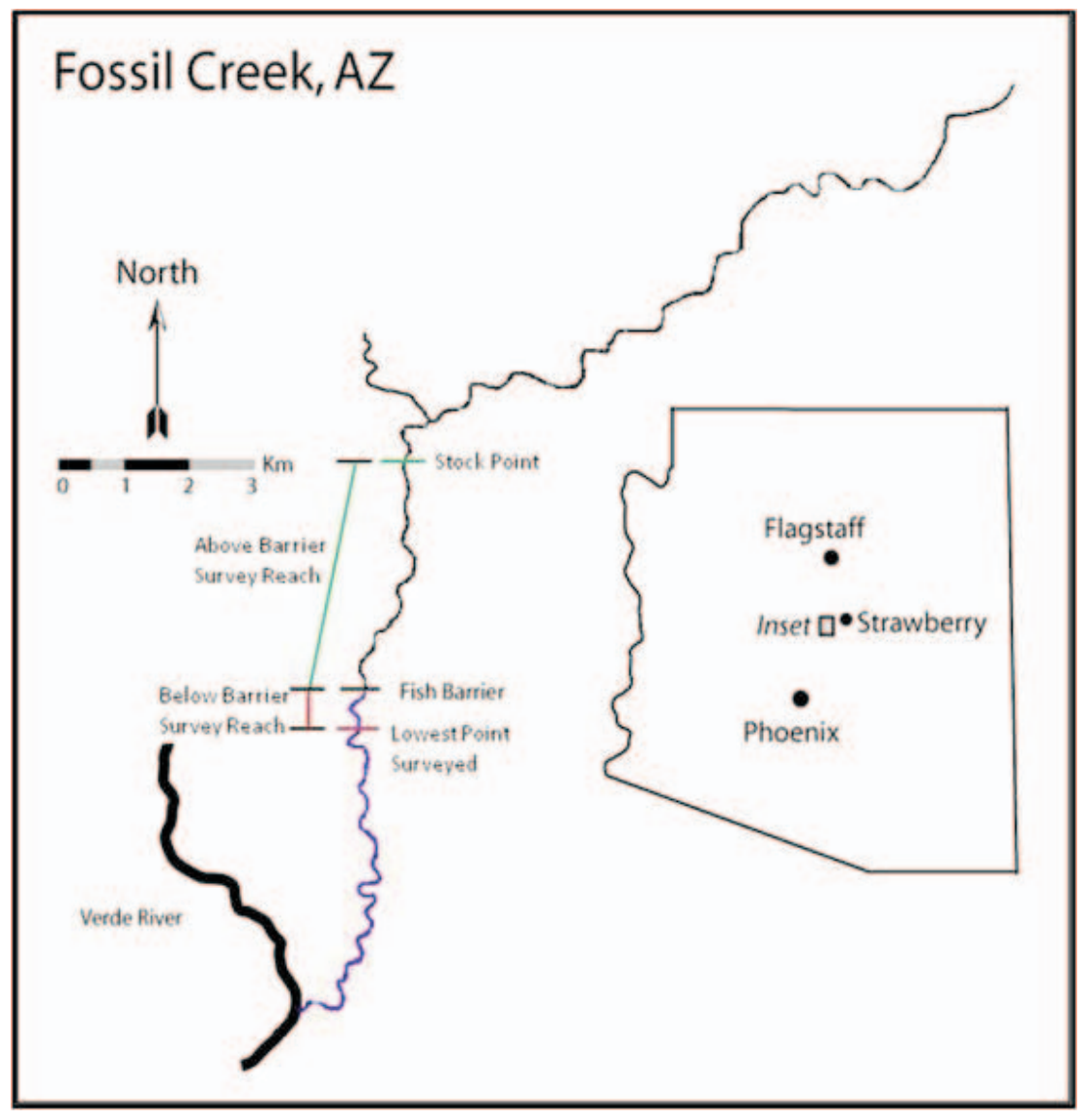

Fig. 1. Map of Fossil Creek, Arizona. Surveys for PIT tags in otter scat were conducted from the release site to approximately $1 \mathrm{~km}$ below the fish barrier. Although the reach below the barrier is considerably shorter than the reach above the barrier, a large proportion of the tags found were in the lower reach.

occur during monsoons in the late summer to early fall and during snowmelt run-off in the early spring. Suspended sediment loads increase during the aforementioned events, but the water is generally clear at all other times (1.1-45.6 NTU [nephelometric turbidity units]; Weedman and Sponholtz 2005). The river drops $1435 \mathrm{~m}$ over a length of approximately $23 \mathrm{~km}\left(62.39 \mathrm{~m} \cdot \mathrm{km}^{-1}\right)$ and ultimately flows into the Verde River.

\section{MEthods}

We obtained 498 razorback suckers from the Hualapai Native Fish Rearing Facility near Peach Springs, Arizona. The fish specimens were originally collected as larvae from wildspawned fish in Lake Mohave, Arizona, and then reared in the ponds at Peach Springs for 2 years. Fish were transported from Peach Springs to the
Bubbling Ponds Native Fish Research Facility (Arizona Game and Fish Department) and maintained in a 36,000-L holding tank for 20 days, during which time the specimens were treated with salt at $3 \mathrm{ppm}$ to remove external parasites. Each fish was PIT tagged with a $134-\mathrm{kHz}$ tag and randomly placed into one of 2 treatment tanks (18,000-L aboveground pools with dimensions $5.8 \times 2 \times 1.4 \mathrm{~m})$.

Each tank had a 4.5-m-long wall of cinder blocks positioned down the longitudinal center and was equipped with a 0.5 -horsepower highefficiency centrifugal pump, an Aquadyne 2.2 bubble bead filter, and an ultraviolet (UV) filter. Both treatment tanks were identical with the exception of the presence of two 10-cm propeller pumps in opposite corners of the exercise tank. The pumps generated unidirectional flow, which was heterogeneous throughout the exercise 
treatment tank but averaged approximately 30 $\mathrm{cm} \cdot \mathrm{s}^{-1}$. Flow treatment was continuous for 30 days prior to stocking.

We conducted a laboratory test to determine if exercise conditioning improved swimming ability. We used a flow chamber designed to test a fish's ability to maintain a position in the water column while flow rates increased over time. The 140-cm-long flow-chamber apparatus consisted of 2 clear PVC tubes-a 17-cm-diameter tube suspended within a 24-cm-diameter tube-through which water circulated. A variable-speed motor connected to a propeller at one end enabled flow variation through the apparatus (Mueller et al. 2007).

The flow-chamber trials were conducted 1-3 days prior to stocking. On each test day, a subsample of fish from each group was collected from the treatment tanks and placed in a holding tank. Individual fish were drawn at random from the holding tank so the researcher conducting the test did not know if the specimen was an exercise-conditioned or a nonexercise-conditioned fish. After being placed in the flow chamber, each fish was acclimated at $48 \mathrm{~cm} \cdot \mathrm{s}^{-1}$ for 10 minutes. The water velocity was then increased by $6 \mathrm{~cm} \cdot \mathrm{s}^{-1}$ every 5 minutes until the fish failed (i.e., was unable to maintain a position in the water column). Failure was realized when the fish was forced onto the safety screen at the back of the unit and made no effort to free itself even after the motor was turned off and the water velocity reduced. After a fish failed, the motor speed at the point of failure was recorded and used to determine water velocity. We conducted tests on 12 fish from each treatment group (total of 24 fish). The water velocities recorded at failure and durations of trials were compared using one-tailed $t$ tests.

The fish were released into Fossil Creek on 4 December 2008. The release site was the lowest road-accessible site in Fossil Creek $\left(34^{\circ}\right.$ $\left.22^{\prime} 43.7^{\prime \prime} \mathrm{N}, 111^{\circ} 39^{\prime} 28.2^{\prime \prime} \mathrm{W}\right), 3.2 \mathrm{~km}$ above the concrete fish barrier. Of the 482 fish stocked, 242 were exercise-conditioned (mean total length, $296 \mathrm{~mm}$ ) and 240 were nonexercised fish (mean total length, $295 \mathrm{~mm}$ ). Although the intended method of field data collection via PIT antennas and a remote communication station failed because the released razorback suckers were preyed upon by river otters (Lontra canadensis), the implanted PIT tags were retained in the otter scat which enabled an alternative data collection method. One week after the initial re- lease, we found a PIT tag in otter scat located just below the fish barrier. An immediate survey of both banks of the river for approximately $1 \mathrm{~km}$ downstream of the barrier resulted in the recovery of 12 readable tags.

We conducted 3 additional surveys for otter scat 2-3 weeks after the release date by walking the banks of the river and searching for scat piles, focusing our search within the riparian zone. We searched from the release site to $1 \mathrm{~km}$ below the fish barrier (Fig. 1). Otter scat was concentrated in sandy areas under cliff overhangs, atop boulders and cobbles, and along pools where there were larger areas of bedrock and/or otter "slides." When a scat pile was encountered, it was searched and removed. In areas with loose substrate, such as grass or sand, we scanned the area with a Destron FS2001 ISO portable tag reader. Several tags were detected in this manner. A location was recorded for each PIT tag by using a GPS receiver; the locations were used to conduct distributional analysis. Fossil Creek remained at base flow throughout this survey period. A warm winter storm resulting in a high-flow event (no gauging station, magnitude unknown) occurred at the beginning of January 2009. Surveys that occurred within 2 weeks after this event produced no new tags, though fresh otter scat was encountered. We used a one-tailed $t$ test to evaluate if tags from nonexercised fish had a different distribution than those from exercised fish. A one-tailed Fisher's exact test and $\chi^{2}$ tests were also used to analyze distributions of control and treatment fish above and below the fish barrier.

Fossil Creek is impacted heavily by human visitation above the release site, and otter scat was rarely encountered there during earlier field observations, presumably because of low otter presence. Though they were not part of the regular survey reach, we searched the banks $500 \mathrm{~m}$ above the release site toward the end of the survey period; no PIT tags were recovered in that area.

\section{RESUlts}

Mean failure velocities in the flow chamber were $62.8 \mathrm{~cm} \cdot \mathrm{s}^{-1}(\mathrm{SE}=2.40)$ for the nonexercised fish and $87.8 \mathrm{~cm} \cdot \mathrm{s}^{-1}(\mathrm{SE}=2.16)$ for the exercise-conditioned fish (one-tailed $t$ test: $\mathrm{df}=$ $22, P<0.0001)$. The exercise-conditioned fish were able to maintain position in the flow chamber twice as long as the nonexercised fish (onetailed $t$ test, $\mathrm{df}=22, P<0.0001$; Fig. 2). 

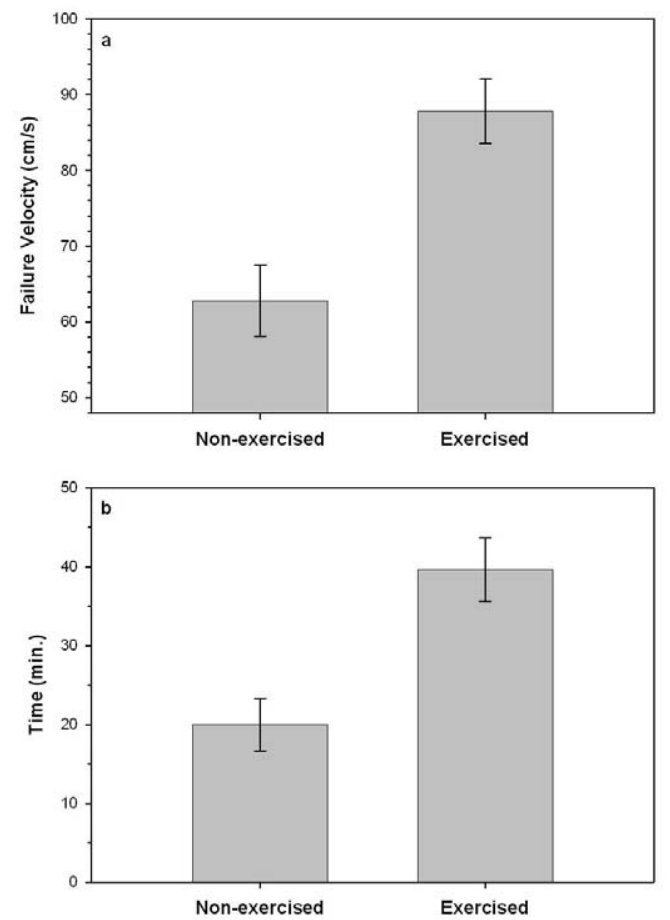

Fig. 2. A subsample of each treatment group having similar mean total length and mass (2-tailed $t$ tests: $P>0.05$ ) was tested for the ability to maintain a position in the water column inside a flow tube with variable water velocity. Panel a: The mean water velocity at which exercised razorback suckers "failed" was significantly higher $\left(87.83 \mathrm{~cm}^{\cdot} \mathrm{s}^{-1}\right)$ than that at which nonexercised razorback suckers "failed" $\left(62.83 \mathrm{~cm} \cdot \mathrm{s}^{-1}, P<0.0001\right)$. Panel b: Exercised razorback suckers also were in the flow tube for 1.98 times as long as nonexercised razorback suckers.

In all, we recovered 36 readable tags. Recovered PIT tags from the nonexercised fish were found significantly farther downstream from the stocking point than the PIT tags from the exercised fish (nonexercised fish: $n=22, \bar{x}=3370 \mathrm{~m}$; exercised fish: $n=14, \bar{x}=2479 \mathrm{~m}$; one-tailed $t$ test: $\mathrm{df}=34, P=0.002$; Fig. 3). Tags from each treatment group were not distributed randomly above and below the barrier (one-tailed Fisher's exact: $P=0.041$ ). Tags from exercised fish were equally distributed above and below the barrier, but significantly more nonexercised fish were found below the barrier than above $\left(\chi^{2}=6.545, \mathrm{df}=1, P=0.011\right)$.

\section{Discussion}

Lab tests demonstrated that the 2 treatment groups of razorback suckers differed in their

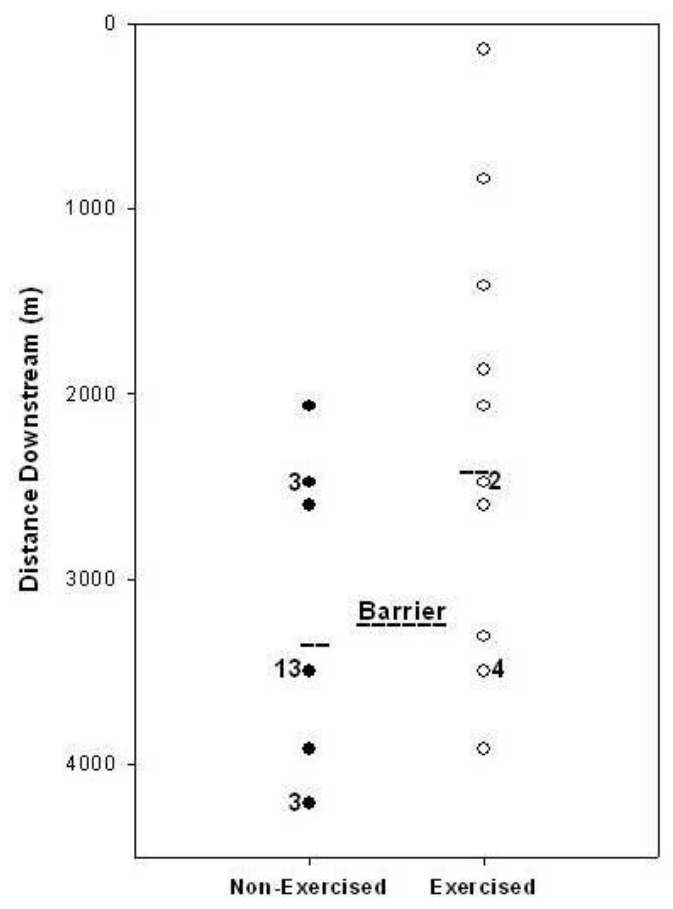

Fig. 3. Locations where PIT tags were recovered. Numbers are associated with locations where multiple tags were recovered and indicate the number of tags recovered at that location over all surveys. Lines indicate the mean of each distribution.

swimming capabilities prior to release into Fossil Creek, with exercised fish better able to maintain a position in the flow chamber. Ward and Hilwig (2004) also found a positive effect after just 10 days of exercise conditioning razorback suckers. However, our flow-chamber results contrast with those reported in a similar lab study by Mueller et al. (2007), who found no significant difference between treatments for razorback suckers. This may be due to the differences in conditioning regimes used, flow-tube testing procedure, or sample size. The conditioning regime used by Mueller et al. (2007) created flow only during normal business hours, gradually increasing the water velocity to $30 \mathrm{~cm} \cdot \mathrm{s}^{-1}$. Our regime was continuous and averaged approximately $30 \mathrm{~cm} \cdot \mathrm{s}^{-1}$ from the beginning of the treatment period, though the treatment period was shorter overall. Our initial flow-chamber acclimation velocity was also higher and our incremental time periods shorter than those in Mueller et al. (2007). Our swim tests may have been better able to detect differences between 
exercised and nonexercised fish, as the test conditions were more physically rigorous.

The field data indicate that the nonexercised fish were moving downstream farther than the exercised fish. Though there is no resolute time stamp associated with any one datum and thus rate could not be calculated, all tags were collected within the same time frame, and PIT tags from the nonexercised fish were found farther downstream from the release point than the tags from the exercised fish. Additionally, there were proportionally more PIT tags from nonexercised fish below the barrier than above the barrier. This again indicates that nonexercised fish were moving downstream faster, farther, and in larger numbers than exercised fish.

Our study expanded on a similar study by Mueller et al. (2003) by experimenting in a different environment. Mueller et al. (2007) released exercised and nonexercised razorback suckers into a large backwater that is generally more consistent with razorback sucker habitat. We released fish into an environment with higher flow rates and attained similar results. While the number of exercise-conditioned and nonexercised fish released was much greater in our study, the actual sample size of recovered PIT tags was similar to the number of fish released by Mueller et al. $(n=30)$. The results of our study corroborate their finding that exercise conditioning reduces movement from a release site.

Data on river otter feeding and movements suggest that scat is dropped close to feeding sites. Gut passage rates are 167-188 minutes (White et al. 2007), and the average distance traveled per day is $0.63 \mathrm{~km}$ in Verde River tributaries (Christensen 1984). Any movement of PIT tags by otters was likely random with respect to treatment group and is not believed to have altered the significance of the result. Although river otters could have moved between collection and deposition of tags, there were typically several piles of fresh scat present where otter scats containing PIT tags were found. This indicates that the otters were likely residing at that particular feeding spot until the resources were depleted in that spot.

Both groups of experimental razorback suckers were naïve to river otters as predators. However, there were $57 \%$ more tags from nonexercised than from exercised razorback suckers recovered from otter scat. Predator recognition experiments have shown that predation in the wild can be reduced on fish reared in protected environments by exposing them to piscivorous/omnivorous fishes in the lab (Johnson et al. 1993, Mueller et al. 2007). Perhaps exercise in conjunction with predator recognition trials may be effective in increasing survival of hatchery-reared fish after release.

Even though the exercise conditioning reduced downstream movement, all recovered PIT tags from released razorback suckers were distributed downstream of the release site. Razorback suckers are big river fish that were historically common in drainages with lower gradients and higher suspended sediment loads (Tyus and Karp 1990), such as the Colorado River and its major tributaries. The Grand Canyon reach of the Colorado River, for example, has a gradient from approximately $0.2 \mathrm{~m} \cdot \mathrm{km}^{-1}$ to about $0.34 \mathrm{~m} \cdot \mathrm{km}^{-1}$ and the pre-dam median sediment load at the Grand Canyon gauging station was $1250 \mathrm{ppm}$ with peaks of up to 21,000 ppm (Howard and Dolan 1981). Although Fossil Creek is a sizable stream for the Southwest, its physical characteristics are quite different from these larger rivers. It has a high gradient (approximately $62.39 \mathrm{~m} \cdot \mathrm{km}^{-1}$ ) and a very low suspended sediment load during base flow (<3 ppm to $20.8 \mathrm{ppm}$; Weedman and Sponholtz 2005). The downstream movement we observed was possibly a behavioral response to a lack of appropriate razorback sucker habitat. The high gradient of Fossil Creek, particularly of the reach in which this group of fish was released, may be too steep for razorback suckers, even those with exercise conditioning. Even if gradient were not an issue, the low suspended sediment load may increase vulnerability of razorback suckers to predation (Johnson and Hines 1999), enough that any introduced stocks in the presence of river otters would likely fail.

As part of other research projects, hoop-netting and snorkel surveys have been conducted in the reach from our release site to below the fish barrier. No razorback suckers have been detected in the area using these methods, indicating that it is not likely that many stocked razorback suckers remain. This is another indication that Fossil Creek may not contain suitable habitat for razorback suckers.

Exercise conditioning appears to increase the physiological condition of razorback suckers. This result was clearly indicated in the lab tests and, to a lesser degree, in our field observations. Because river otters preyed on stocked razorback suckers in Fossil Creek, we were able to 
collect some valuable data on poststocking fish movement, as well as inform fish managers that predation by otters may affect survival of stocked razorback suckers in the Southwest.

\section{ACKNOWLEDGMENTS}

This work was part of Luke Avery's thesis work at Northern Arizona University and was funded by the university's Environmental Research, Development, and Education for the New Economy (ERDENE) program. Many components of this project were labor intensive, and the research could not have been accomplished without the aid of several people in Jane Marks' lab and several local biologists in the U.S. Fish and Wildlife Service. Three anonymous referees provided valuable feedback on a previous version of this manuscript.

\section{Literature Cited}

Christensen, K.M. 1984. Habitat selection, food habits, movements, and activity patterns of reintroduced river otters (Lutra canadensis) in central Arizona. Master's thesis, Northern Arizona University, Flagstaff, AZ.

FARLINGER, S., AND F.W.H. BEAMISH. 1978. Changes in blood chemistry and critical swimming speed of largemouth bass, Micropterus salmoides, with physical conditioning. Transactions of the American Fisheries Society 107:523-527.

Howard, A., and R. Dolan. 1981. Geomorphology of the Colorado River in the Grand Canyon. Journal of Geology 89:269-298.

Jobling, M., B.M. BAARDVIK, J.S. Christiansen, AND E.H. JORGENSEN. 1993. The effects of prolonged exercise training on growth performance and production parameters in fish. Aquaculture International 1:95-111.

Johnson, J.E., AND R.T. Hines. 1999. Effect of suspended sediment on vulnerability of young razorback suckers to predation. Transactions of the American Fisheries Society 128:648-655.

Johnson, J.E., M.G. Pardew, and M.M. LytTLe. 1993. Predator recognition and avoidance by larval razorback sucker and northern hog sucker. Transactions of the American Fisheries Society 122:1139-1145.

LEON, K.A. 1986. Effect of exercise on feed consumption, growth, food conversion, and stamina of brook trout. Progressive Fish Culturist 48:43-46.

Marsh, P.C., AND J.E. BRooks. 1989. Predation by ictalurid catfishes as a deterrent to reestablishment of hatcheryreared razorback suckers. Southwestern Naturalist 34:188-195.

Marsh, P.C., B.R. Kesner, and C.A. Pacey. 2005. Repatriation as a management strategy to conserve a critically imperiled fish species. North American Journal of Fisheries Management 25:547-556.

Marsh, P.C., and D.R. Langhorst. 1988. Feeding and fate of wild larval razorback sucker. Environmental Biology of Fishes 21:59-67.

Marsh, P.C., AND W.L. MincKLEy. 1990. Observations on recruitment and ecology of razorback sucker: lower
Colorado River, Arizona-California-Nevada. Great Basin Naturalist 49:71-78.

Marsh, P.C., C.A. PaceY, and B.R. Kesner. 2003. Decline of the razorback sucker in Lake Mohave, Colorado River, Arizona and Nevada. Transactions of the American Fisheries Society 132:1251-1256.

Miller, R.R., J.D. Williams, and J.E. Williams. 1989. Extinctions of North American fishes during the past century. Fisheries 14:22-38.

MinCKLEY, W.L. 1990. Native fishes of the Grand Canyon region: an obituary? Pages 124-177 [chapter 7] in Colorado River ecology and dam management, proceedings of a symposium, May 24-25.

MinckLey, W.L., AND J.E. Deacon. 1968. Southwestern fishes and the enigma of "endangered species." Science 159:1424-1432.

Modde, T., K.P. Burnham, and D.J. Wick. 1996. Population status of the razorback sucker in the middle Green River. Conservation Biology 10:110-119.

Modde, T., AND D.B. Inving. 1998. Use of multiple spawning sites and seasonal movement by razorback suckers in the Middle Green River, Utah. North American Journal of Fisheries Management 18:318-326.

MueLLeR, G.A. 2003. The role of stocking in the reestablishment and augmentation of native fish in the lower Colorado River mainstream (1998-2002). U.S. Geological Survey Open-File report 03-288. 43 pp.

2006. Ecology of bonytail and razorback sucker and the role of off-channel habitats in their recovery. U.S. Geological Survey Scientific Investigations Report 2006-5065. $63 \mathrm{pp}$

Mueller, G.A., J. Carpenter, R. Krapfel, and C. Figiel. 2007. Preliminary testing of the role of exercise and predator recognition for bonytail and razorback sucker. U.S. Geological Survey Open-File Report 2007-1423. $37 \mathrm{pp}$.

Mueller, G.A., P.C. Marsh, D. Foster, M. Ulibarri, AND T. BURKE. 2003. Factors influencing poststocking dispersal of razorback sucker. North American Journal of Fisheries Management 23:270-275.

Nesler, T.P., K. Christopherson, J.M. Hudson, C.W. MCAda, F. Pfeifer, and T.E. CZAPla. 2003. An integrated stocking plan for the razorback sucker, bonytail, and Colorado pikeminnow for the upper Colorado River Endangered Fish Recovery Program. Addendum to state stocking plans for the states of Colorado and Utah. 12 pp.

PofF, N.L., AND J.D. Olden. 2005. Long-term trends of native and non-native fish faunas in the American Southwest. Animal Biodiversity and Conservation 28:75-89.

RinNe, J.N. 1995. The effects of introduced fishes on native fishes: Arizona, southwestern United States. Pages 149-159 in Protection of aquatic biodiversity, proceedings of the World Fisheries Congress, Theme 3.

Rupert, J.B., R.T. Muth, and T.P. Neslek. 1993. Predation on fish larvae by adult red shiner, Yampa and Green rivers, Colorado. Southwestern Naturalist 38: 397-399.

Ryden, D.W. 2000. Monitoring of experimentally stocked razorback sucker in the San Juan River: March 1994 through October 1997. Final Report, U.S. Fish and Wildlife Service, Grand Junction, CO.

SCHOOLEY, J.D., AND P.C. MARSH. 2007. Stocking of endangered razorback suckers in the Lower Colorado River Basin over three decades: 1974-2004. North American Journal of Fisheries Management 27:43-51. 
Tyus, H.M., AND C.A. KaRP. 1990. Spawning and movements of razorback sucker, Xyrauchen texanus, in the Green River Basin of Colorado and Utah. Southwestern Naturalist 35:427-433.

Tyus, H.M., and J.F. SAunders III. 2000. Non-native fish control and endangered fish recovery: lessons from the Colorado River. Fisheries 25:17-24

WARD, D.L., AND K.D. HiLWIG. 2004. Effects of holding environment and exercise conditioning on swimming performance of southwestern native fishes. North American Journal of Fisheries Management 24: 1083-1087.

Ward, D.L., O.E. Maughan, and S.A. Bonar. 2002. Effects of temperature, fish length, and exercise on swimming performance of age-0 flannelmouth sucker. Transactions of the American Fisheries Society 131:492-497.

WeEdman, D.A., AND P. Sponholtz. 2005. Fossil Creek native fish restoration project. U.S. Bureau of Reclamation, U.S. Fish and Wildlife Service and Arizona Game and Fish Department. Final Project Report. $59 \mathrm{pp}$

White, S.C., D.W. Clark, C.D. Day, and R.S. Sikes, 2007. Variation in digestive efficiency of captive North
American river otters (Lontra canadensis) on various diets. Zoo Biology 26:41-50.

YOUNG PS, AND JJ. CECH JR. 1993. Effects of exercise conditioning on stress responses and recovery in cultured and wild young-of-the-year striped bass, Morone saxatilis. Canadian Journal of Fisheries and Aquatic Sciences 50:2094-2099.

1994a. Effects of different exercise conditioning velocities on the energy reserves and swimming stress responses in young-of-the-year striped bass (Morone saxatilis). Canadian Journal of Fisheries and Aquatic Sciences 51:1528-1534.

1994b. Optimum exercise conditioning velocity for growth, muscular development, and swimming performance in young-of-the-year striped bass (Morone saxatilis). Canadian Journal of Fisheries and Aquatic Sciences 51:1519-1527.

Received 4 March 2010 Accepted 11 November 2010 